\title{
POTENSI PENGEMBANGAN TERNAK SAPI PADA USAHA TANI DIKECAMATAN TARERAN MINAHASA
}

\author{
Riko E. Mirah*, E.K.M. Endoh**, J. Pandey **, A.H.S. Salendu ** \\ Fakultas Peternakan Universitas Sam Ratulangi , Manado, 95115
}

\begin{abstract}
ABSTRAK
Pengembangan peternakan saat ini menunjukan adanya prospek yang sangat cerah dan mempunyai peranan penting dalam pertumbuhan ekonomi pertanian. Permasalahannya sejauh mana potensi sumberdaya lahan, summberdaya manusia dan kapasitas ternak. Berdasarkan permasalahan ini maka dilakukan penelitian dengan tujuan untuk mengetahui potensi pengembangan ternak sapi di Kecamatan Tareran Kabupaten Minahasa Selatan. Penelitian ini dilakukan dengan menggunakan metode survei. Sumber data yang digunakan adalah data primer dan data sekunder. Data primer dikumpulkan dari kantor Kecamatan Tareran dan Kantor BP3K (Balai penyuluhan, pertanian, perikanan dan kehutanan).Data sekunderdiperolehdariinstansi yang berkaitandenganpenelitianini.Model analisis yang digunakan yaitu analisis deskriptif, dan analisis potensi pengembangan ternak efektif.Hasil penelitian menunjukan bahwapotensi maksimum dalam satuan ternak berdasarkan sumberdaya lahan (PMSL) sebesar 5.238,1ST. Kapasitas peningkatan populasi ternak sapi berdasarkan sumberdaya lahan (KKPTR(SL) sebesar 5.058,65 ST, Populasi rill ternak sapi (POPRIL) sebesar 179,45ST, Potensi maksium berdasarkan kepala keluarga (PMKK) sebesar 7.380 ST, dan Kapasitas peningkatan populasi ternak sapi (KPPTR(KK) sebesar 7.200,55 ST. Berdasarkanhasilpenelitiandapatdisimpulkanba hwa wilayah Kecamatan Tareran potensial untuk pengembangan ternak sapi.
\end{abstract}

Kata Kunci : ternak sapi, potensi, pengembangan

\footnotetext{
*Alumni Fakultas Peternakan

** Jurusan Sosial Ekonomi
}

\begin{abstract}
POTENSIAL DEVELOPMENT OF CATTLE IN TARERAN SUB DISTYRICT, MINAHASA.Farm development showed a good prospect and has an important role in the growth of the agricultural economy. The problem is the extent to which the potential of land resources , human resorces and livestock capacity. Based on this problems we performed the research / The aimed of the research was to know potensial development of cattle in District Tareran South Minahasa regency Survey mehode was used. Source of data used are primary data and secondary data . Primary data was collected from the district office and the Office Tareran BP3K ( Hall extension, agriculture, fisheries and forestry ).Secondary data collected from government office that in line with this research. Datal analysis used descriptive analysis, and analysis of the potential for livestock development efektif.Hasil bahwapotensi study showed maximum in livestock units based land resources ( PMSL ) of 5.238,1ST . Capacity increase in the cattle population by land resources ( KKPTR ( SL ) of 5058.65 ST, the real population of cattle ( POPRIL) of $179,45 \mathrm{ST}$, Potential of maximum based head of the family ( PMKK ) for 7380 ST , and capacity enhancement cattle population ( KPPTR ( KK ) of 7200.55 ST ..
\end{abstract}

Keywords : cattle, potential, development

\section{PENDAHULUAN}

Peningkatan jumlah penduduk yang diikuti peningkatan penghasilan per kapita menjadikan masyarakat semakin meningkatkan konsumsi protein hewani. Hal ini membuat pergeseran pola makan 
masyarakat dari mengonsumsi karbohidrat ke protein (hewani), berupa daging, telur, dan susu. Kecenderungan ini diduga menjadi penyebab ketidakmampuan produsen sapi potong memenuhi permintaan dalam negeri. (Zainal Abidin, 2001).

Pemenuhan permintaan akan protein hewani dapat dilakukan dengan cara pengembangan ternak kecil maupun besar. Salah satu jenis ternak yang dapat dikembangkan ialah ternak sapi potong, karena mempunyai beberapa keunggulan diantaranya: 1) ternak sapi mempunyai kandungan gizi yang tinggi, 2) mudah diperdagangkan, budidayanya relatif mudah, 3) hemat tempat dan perputaran modal cepat (Yulianto dan Saparinto,2011).

Potensi peternakan di Minahasa Selatan cukup memadai. Pembangunan pertanian dan peternakan saling mendukung dan menguntungkan, sehingga sistem pertanian terpadu memberi manfaat yang besar bagi keduanya. Di satu sisi, hasil pertanian seperti jagung, ubikayu, rumput-rumputan, limbah pertanian dapat dimanfaatkan sebagai pakan sehingga ada nilai tambahnya. Disisi lain, pupuk kandang sebagai limbah ternak sangat diperlukan sebagai sumber organik bagi tanaman guna menyuburkan tanah, sehingga produktivitas pertanian meningkat. Dampak berikutnya yang secara langsung dirasakan petani adalah peningkatan pendapatan dan kesejahteraan (Salendu, 2012).

KecamatanTareranmempunyaipote nsipengembanganpertanian seperti padi, jagung, ubi-ubian, kacang panjang, kelapa, yang dapat menunjang pengembangan peternakan ternak sapi potong. Disamping itu adanya program pemerintah melalui Dinas Peternakan berupa pembinaan peternak sapi potong di Kecamatan ini dengan membentuk kelompok taniuntuk usaha peternakan sapi potong diharapkan menjadi cikal bakal usaha kecil mikro dan menengah. Kecamatan Tareran memiliki sumberdaya alam dan sumberdaya manusia yang potensial untuk menunjang pengembangan ternak sapi potong. Akan tetapi pada kenyataannya pengembangan ternak sapi potong di wilayah ini belum dilakukan secara efektif. Pemanfaatan ternak sapi di Kecamatan Tareran saat ini sebagai tenaga angkutan yang digunakan untuk mengangkut hasil-hasil pertanian, walaupun ada peternak yang menjadikan usaha sapi potong sebagai penghasil daging. Permasalahannya baik pemerintah maupun petani peternaksapi belum mengetahui sejauh mana potensi sumberdaya lahan, sumber dayamanusia dankapasitas tampung ternak di KecamatanTareran.Berdasarkanpermasala 
hantersebut maka perlu dilakukan penelitian secara komprehensif untuk mengetahui berapa besar potensi sumberdaya lahan dan sumber daya manusia yang dapat menunjang pemeliharaan ternak sapi dan efektifitas potensi pengembangan ternak sapi di Kecamatan Tareran. (BP3K Kecamatan Tareran,2013)

\section{METODE PENELITIAN}

Lokasi penelitian ditentukan secara sengaja dan mengambil tempat di KecamatanTareranKabupatenMinahasa Selatan dengan pertimbangan daerahinimemilikipopulasiternaksapi yang dapatdikembangkankearah yang lebihbaik. Sumber data yang digunakan dalam penelitian ini adalah data primer dan data sekunder.Data primer adalah data yang dikumpulkan dari kantor Kecamatan Tareran dan Kantor BP3K(Balai penyuluhan, pertanian, perikanan dan kehutanan) Kecamatan Tareran Kabupaten Minahasa Selatan.Data sekunder diperoleh dari instansi yang terkait dengan penelitian ini.Model analisis data yang dipergunakan untuk menjawab tujuan pertama dalam penelitian ini yaitu analisis deskriptif (Jogianto, 2008). Untuk menjawab tujuan kedua digunakan analisis potensi daya tampung dan kapasitas daya tampung wilayah pengembangan ternak sapi potong efektif di Kecamatan Tareran Kabupaten Minahasa Selatan, melalui analisis potensi pengembangan ternak efektif menurut Salendu (2012).

\section{HASIL DAN PEMBAHASAN}

Sumberdaya alam mempunyai peranan yang penting dalam pembangunan pertanian yang menunjang pembangunan ekonomi. Kemajuan suatu wilayah tergantung pada potensi sumberdaya alam yang dimiliki dan kemampuan sumberdaya manusia yang mengelolanya. Ketersediaan sumberdaya alam di Kecamatan Tareran membuat masyarakat mengoptimalkan kerja usaha taninya. Upaya meningkatkan dan melestarikan sumber daya alam sangat dibutuhkan untuk bisa memaksimalkan potensi serta peluang usaha yang berbedah-bedah. Menurut Sugeng (2009), sumberdaya alam adalah sesuatu yang dapat dimanfaatkan untuk berbagai kepentingan dan kebutuhan hidup manusia, contoh dasar sumberdaya alam seperti lahan yang dimanfaatkan untuk pengembangan ternak ruminansia dan tumbuh-tumbuhan.

Luas wilayah Kecamatan Tareran $12.938 \mathrm{Km}^{2}$ yang diklasifikasikan menurut ekosistem dan penggunaannya, sebagai berikut: Lahan kering 5.481 ha yang terdiri dari lahan perkebunan 1406 ha, tegalan 1327 ha dan hutan 2748 ha. Lahan rawa 
589 ha yang terdiri dari lahan sawah 487

ha, dapat lihat pada Tabel 1.

ha dan kolam 102 ha. Padang rumput 293

Tabel 1. Luas Lahan Menurut Penggunaannya di Kecamatan Tareran Kabupaten Minahasa Selatan

\begin{tabular}{llrr}
\hline No. & \multicolumn{1}{c}{ JenisPenggunaan Tanah/Lahan } & Luas $(\mathrm{Ha})$ & Presentase (\%) \\
\hline 1. & Tanah/LahanKering & $(5481)$ & $(86,14)$ \\
& a. Perkebunan & 1406 & 22,09 \\
& b. Tegalan/Ladang & 1327 & 20,85 \\
& c. Hutan & 2748 & 43,18 \\
2. & Tanah/LahanRawa & $(589)$ & $(9,26)$ \\
& a. Sawah & 487 & 7,65 \\
& b. Kolam & 102 & 1,60 \\
3. & Padang Rumput & $(239)$ & $(4,60$ \\
\hline \multicolumn{2}{r}{ Tot a I } & 6.363 & 100,00 \\
\hline
\end{tabular}

Sumber :BP3K Kecamatan Tareran Minahasa Selatan (2013)

Berdasarkan Tabel 1 dapat diketahui penggunaan lahan terbesar adalah Lahan kering sebesar 5481 ha atau $86,14 \%$. Sedangkan penggunaan lahan terkecil adalah padang rumput 293 ha atau 4,60\% (BP3K Kecamatan Tareran, 2013)

Sumberdaya pertanian yang terdapat di Kecamatan Tareran Kabupaten Minahasa Selatan yaitu padi sawah, padi ladang, jagung, ubi kayu, ubi jalar, kacang tanah, kacang hijau, kacang merah, kacang panjang, kedelai, bawang merah, dan daun bawang. Luas tanam keseluruhannya berjumlah 1.971 ha dan luas panen keseluruhan berjumlah 1.757 ton.

Sumberdaya perkebunan terdiri dari kelapa, cengkih, pala, kakao, vanili, kopi, Aren, dan Cassiavera. Luas areal keseluruhannya berjumlah 2,733 dan produksi keseluruhan $1.309,587$ ton. Penduduk Kecamatan Tareran Kabupaten
Minahasa Selatan berusaha di bidang pertanian dan perkebunan dengan bermacam-macam komoditi. Menurut Suryana (2000), mayoritas penduduk desa berprofesi sebagai petani dan buru tani yang sangat berpengalaman dan mahir menghasilkan komoditi pertanian dan perkebunan

Populasi ternak menurut jenis di Kecamatan Tareran terdiri dari ternak besar, ternak sedang dan ternak unggas. Ternak sapi potong berjumlah 184 ekor, ternak babi 900 ekor, ternak kuda 117 ekor, ternak kambing 79 ekor, ternak ayam buras 10.000 ekor, ternak ayam petelur 152 , ternak ayam pedaging 143 , dan ternak itik 126. Ternak ayam buras merupakan populasi terbesar diantara ternak lainnya.Usaha ternak besar, khususnya ternak sapi yang ada di Kecamatan Tareran Kabupaten Minahasa Selatan masih berskala kecil dan merupakan usaha 
sampingan, sedangkan luas lahan yang tersedia dan ketersediaan pakan cukup besar. Hal ini menunjukan bahwa usaha tani mempunyai prospek yang cerah untuk dikembangkan.

Sumberdaya manusia merupakan faktor penting dalam pembangunan, karena pada akhirnya manusia yang menentukan berhasil atau gagalnya pembangunan suatu wilayah. Pembangunan dimaksud diperlukan sumberdaya manusia yang terampil dan inovatif. Hal ini sejalan dengan pendapat Soetrisno (1999) bahwa peningkatan sumberdaya manusia disini tidak dibatasi maknanya dalam artian peningkatan produktivitas mereka saja, namun yang tidak kalah penting adalah untuk meningkatkan kemampuan para petani agar dapat lebih berperan dalam berbagai proses pembangunan. Soemarto (1997) mengemukakan bahwa lingkungan sosial budaya dan ekonomi sangatlah penting bagi kesinambungan pembangunan berkelanjutan, sebab pembangunan dilakukan oleh dan untuk manusia yang hidup dalam sosial budaya dan ekonomi tertentu.

Masyarakat Kecamatan Tareran sebagian besar bekerja sebagai petani di bidang produksi pertanian, berbagai jenis pekerjaan petanipun sangat beragam dengan mengandalkan ketrampilan bercocok tanam serta dalam pemeliharaan jenis ternak yang berbeda disuatu desa. Tenaga kerja di Kecamatan Tareran sebagian besar bekerja di usaha pertanian, tetapi ada juga yang telah bermigrasi ke kota. Hal ini disebabkankarenamasyarakat mencari kesempatan serta peluang kerja yang baru dalam meningkatkan pendapatan.Data jumlah penduduk menurut klasifikasi umur di Kecamatan Tareran berdasarkan BPS Kecamatan Tareran (2013),dapatdilihatpadaTabel 2.

Tabel 2 : Jumlah Penduduk Menurut Klasifikasi Umur di Kecamatan Tareran

\begin{tabular}{lcrr}
\hline No. & KelompokUmur & Jumlah $($ Jiwa $)$ & Presentase $(\%)$ \\
\hline 1. & $0-10$ & 1135 & 8,51 \\
2. & $11-20$ & 1470 & 11,02 \\
3. & $21-30$ & 2528 & 18,95 \\
4. & $31-40$ & 2724 & 20,43 \\
5. & $41-50$ & 2372 & 17,78 \\
6. & $51-60$ & 1856 & 13,92 \\
7. & $>60$ & 1253 & 9,38 \\
\hline
\end{tabular}

Sumber: BP3K Kecamatan Tareran (2014)

Berdasarkan Tabel 2 menunjukkan klasifikasi umur terbesar adalah umur 31 sampai umur 40 dengan jumlah 2.724 atau 20,43\%. Kenyataan umur tersebut 
menunjukan tenaga kerja yang ada di Kecamatan Tareran sudah aktif bekerja, sedangkan penduduk pada umur terkecil adalah umur 0 sampai umur 10 dengan jumlah 1.135 atau $8,51 \%$. Petani peternak di Kecamatan Tareran terbanyak berada pada umur produktif 41-50 tahun. Kepala keluarga petani yang ada di Kecamatan Tareran sangat bervariasi karena ada yang memiliki 2 pekerjaan sekaligus yaitu petani peternak,dan ada juga kepala keluarga petani berprofesi hanya sebagai petani saja (BPS Kecamatan Tareran, 2013). Hasil analisis potensi maksimum sumberdaya lahan di Kecamatan Tareran dapat dilihat pada Tabel3. Data pada Tabel 3 menunjukkan potensi maksimum sumberdaya lahan kering, padang rumput, dan lahan rawa adalah sebesar 5.238,1 ST. Artinya berdasarkan sumberdaya lahan di Kecamatan Tareran masih dapat menampung populasi ternak sapi sebesar nilai PMSL(5.238,1 ST). Populasi rill ternak sapi(POPRIL) di Kecamatan Tareran sebesar 179,45 ST. Nilai ini menunjukkan populasi rill ternak sapi masih kurang sehingga perlu ditingkatkan.

Tabel 3. Hasil analisis PMSL Kecamatan Tareran Kabupaten Minahasa Selatan

\begin{tabular}{lcc}
\hline No. & Koefisien/Variabel & Kecamatan Tareran \\
\hline 1. & $\mathrm{a}$ & 0,8 \\
2. & $\mathrm{LG}$ & 5.481 \\
3. & $\mathrm{~b}$ & 0,5 \\
4. & $\mathrm{PR}$ & 293 \\
5. & $\mathrm{c}$ & 1,2 \\
6. & $\mathrm{R}$ & 589 \\
7. & PMSL & $5.238,1$ \\
\hline
\end{tabular}

Keterangan :

PMSL = Potensi maksimum dalam satuan ternak sapi (ST) berdasarkan sumberdaya, yaitu sapi dewasa $=1,00 \mathrm{ST} / \mathrm{Ha}$, sapi muda $=0,60 \mathrm{ST} / \mathrm{Ha}$ dan sapi anak $=$ $0,25 \mathrm{ST} / \mathrm{Ha}$

$\mathrm{a}=$ Koefisien yang dihitung berdasarkan ratio populasi ternak ruminansia dalam satuan ternak (ST) dengan luas lahan garapan atau lahan kering adalah 0,8 $\mathrm{ST} / \mathrm{Ha}$

$\mathrm{LG}=$ Luas lahan kering di Kab/Kec yang diteliti $(\mathrm{Ha})$

$\mathrm{b} \quad=$ Koefisien yang dihitung sebagai kapasitas tampung padang rumput alam $=0,5$ $\mathrm{ST} / \mathrm{Ha}$

$\mathrm{PR} \quad=$ Luas padang rumput $(\mathrm{Ha})$

$\mathrm{c}=$ Koefisien yang dihitung sebagai kapasitas tampung rawa (1,2 $\mathrm{ST} / \mathrm{Ha})$

$\mathrm{R}=$ Luas Rawa 
Hasil analisis kapasitas Kecamatan Tareran masih dapat peningkatan populasi ternak sapi ditingkatkan sebanyak 5.058,65 ST. berdasarkan SD lahan KPPTR(SL) dilihat padaTabel 4.Data Tabel 4 menunjukkan kapasitas peningkatan populasi ternak sapi berdasarkan SD lahan di Kecamatan Tareran sebanyak 5.058,65 ST. Artinya untuk memenuhi potensi maksimum SD Tingkat ketersediaan hijauan makanan ternak pada suatu wilayah merupakan salah satu faktor yang sangat penting dalam meningkatkan populasi dalam keberhasilan pengembangan ternak khususnya ternak ruminansia.

lahan maka populasi ternak sapi di

Tabel 4. Hasil Analisis KPPTR(SL) Kecamatan Tareran Kabupaten Minahasa Selatan

\begin{tabular}{lcr}
\hline No. & Koefisien/Variabel & Kecamatan Tareran \\
\hline 1. & PMSL & $5.238,10$ \\
2. & POPRIL & 179,45 \\
3. & KPPTR (SL) & $5.058,65$ \\
\hline
\end{tabular}

\section{Keterangan:}

$\operatorname{KPPTR}(\mathrm{SL}) \quad=$ Kapasitas peningkatan populasi ternak sapi $(\mathrm{ST})$ berdasarkan sumberdaya lahan

POPRIL = Populasi rill ternak sapi $(\mathrm{ST})$ di Kabupaten/Kecamatan yang diteliti

$$
\text { Menurut Irawan (2005),lahan dengan perencanaan pengembangan }
$$

pertanian memiliki potensi yang cukup besar sebagai sumber pakan. Oleh karena itu evaluasi hijauan pakan yang ditunjukan untuk memprediksi potensi ternak diwilayah yang diteliti perlu dilakukan untuk mendukung kapasitas peningkatan populasi ternak ruminansia berkaitan wilayah sesuai dengan potensi.

Jumlah kepala keluarga petani di Kecamatan Tareran sebanyak 2.460 KK. Hasil analisis potensi maksimum berdasarkan KK petani (PMKK) dapat dilihat pada Tabel 5 .

Tabel 5. Hasil Analisis PMKK Kecamatan Tareran Kabupaten Minahasa Selatan

\begin{tabular}{lcr}
\hline No. & Koefisien/Variabel & Kecamatan Tareran \\
\hline 1. & $\mathrm{~d}$ & 3 \\
2. & KK & 2.460 \\
3. & PMKK & 7.380 \\
\hline
\end{tabular}

Keterangan :

PMKK = Potensi Maksimum (ST) berdasarkan kepala keluarga petani 
$\mathrm{d}=$ Koefisien yang dihitung berdasarkan jumlah satuan ternak sapi yang dipelihara oleh satu keluarga petani tanpa harus menyewa tenaga kerja luar keluarga = 3ST/KK

KK = Kepala keluarga petani

Data Tabel 5 menunjukan potensi maksimum berdasarkan KK petani di Kecamatan Tareran adalah sebesar 7.380 ST. Artinya berdasarkan ketersediaan TK, dengan masing-masing memiliki 3 ST, maka populasi ternak sapi masih dapat ditingkatkan sampai 7.380 ST. Menurut Soewardi (1985), kapasitas peningkatan populasi ternak sapi berdasarkan kepala keluarga petani merupakan suatu pendekatan untuk menunjukan kapasitas wilayah dalam tersediaanya tenaga kerja untuk mengelolah ternak sapi. Metode tersebut didasarkan atas sumberdaya manusia yang ada, yaitu satuan ternak dan potensi maksimum kepala keluarga petani (PMKK).

Hasil analisis kapasitas peningkatan populasi ternak sapi berdasarkan selisih potensi maksimum dan populasi riil Tahun $2014 \operatorname{KPPTR}(\mathrm{KK})$ dapat dilihat pada Tabel 6 .

Tabel 5. Hasil Analisis PMKK Kecamatan Tareran Kabupaten Minahasa Selatan

\begin{tabular}{lcr}
\hline No. & Koefisien/Variabel & Kecamatan Tareran \\
\hline 1. & $\mathrm{~d}$ & 3 \\
2. & $\mathrm{KK}$ & 2.460 \\
3. & PMKK & 7.380 \\
\hline
\end{tabular}

Keterangan :

PMKK = Potensi Maksimum (ST) berdasarkan kepala keluarga petani

$\mathrm{d}=$ Koefisien yang dihitung berdasarkan jumlah satuan ternak sapi yang dipelihara oleh satu keluarga petani tanpa harus menyewa tenaga kerja luar keluarga = 3ST/KK

$\mathrm{KK}=$ Kepala keluarga petani

Hasil analisis $\mathrm{KPPTR}(\mathrm{KK})$ pada

Tabel 6menunjukkan peningkatan populasi ternak sapi berdasarkan KK petani di Kecamatan Tareran masih kurang sehingga perlu ditingkatkan sampai sebesar 7.200,55 ST.

\section{KESIMPULAN}

Berdasarkan hasil penelitian dapat disimpulkan bahwaKecamatan Tareran mempunyai potensi yang sangat besar dalam meningkatkan populasi ternak sapi dilihat dari sumberdaya lahan yang tersedia, penyediaan makanan ternak dan penyediaan tenaga kerja. Potensi 
maksimum dalam satuan ternak berdasarkan sumberdaya lahan (PMSL) sebesar 5.238,1ST. Kapasitas peningkatan populasi ternak sapi berdasarkan sumberdaya lahan (KKPTR(SL) sebesar 5.058,65 ST. Populasi rill ternak sapi (POPRIL) sebesar 179,45ST. Potensi maksium berdasarkan kepala keluarga (PMKK) sebesar 7.380 ST, dan kapasitas peningkatan populasi ternak sapi (KPPTR(KK) sebesar 7.200,55 ST. Angka ini menunjukan bahwa wilayah Kecamatan Tareran potensial untuk pengembangan ternak sapi.

\section{DAFTAR PUSTAKA}

BP3K Kecamatan Tareran. 2013. Data Statistik BP3K Kecamatan Tareran, Kecamatan Tareran Kabupaten Minahasa Selatan.

Balai Pusat Statistik. 2013. Kecamatan Tareran Kabupaten Minahasa Selatan.

Jogiyanto. 2008. Analisa dan Desain. Edisi VI Yogyakarta

Salendu, A.H.S. 2012. Perspektif Pengelolaan Agroekosistem Kelapa-Ternak Sapi di Minahasa Selatan. Disertasi Program Pascasarjana Fakultas Pertanian Universitas Brawijaya, Malang.

Sugiyono. 2009. Metode Penelitian Bisnis. Bandung, Pusat Bahasa Depdiknas.
Sugeng. 2009. Potensi Sumberdaya Alam Bagi Kehidupan Manusia. Penebar Swadaya, Jakarta.

Suryana, A. 2000. Peran Sektor Pertanian Dalam Memenuhi Kecukupan Pangan Nasional. Kerjasama IPPTP Denpasar Dengan Universitas Udayana, Denpasar. Pustaka.litbang.deptan.go.id Soemarto. 1997. Manajemen Sumber Daya Manusia, Edisi 2, BPFE, Yogyakarta.

Irawan, B. 2005. Konservasi Lahan Pertanian: Potensi Dampak, Pola Pemanfaatannya, dan Faktor Determinan. Forum Penelitian Agro Ekonomi. Bogor: Pusat Analisis Sosial Ekonomi dan Kebijakan Pertanian.

Purnawan, Y dan S. Chayo. 2011. Penggemukan Sapi Potong. Penerbit Penebar Swadaya, Jakarta. Zainal, A.2001.TeknikMempersiapkan, Mendirikan, danMenjalankan UsahaPenggemukanSapiPotong. Jakarta. 